\title{
Influence of Hot Spring Phages on Community Carbon Metabolism: Win, Lose or Draw?
}

\author{
Raymond Kepner \\ Department of Biology, Marist College, Poughkeepsie, New York, USA \\ Email: ray.kepner@marist.edu
}

Received 21 July 2015; accepted 24 August 2015; published 27 August 2015

Copyright (C) 2015 by author and Scientific Research Publishing Inc.

This work is licensed under the Creative Commons Attribution International License (CC BY). http://creativecommons.org/licenses/by/4.0/

(c) $\underset{\mathrm{EY}}{0}$ Open Access

\begin{abstract}
Abundant virus-like particles were concentrated from large-volume samples from two hot springs. Both addition of viral concentrates and addition of samples induced by addition of mitomycin-C changed patterns of carbon source utilization by hot spring microbial communities. Specific effects of the two treatments depended upon both temperature and incubation period. Increased metabolic capability with greater exposure to free phages, consistent with the view that phages are major lateral transporters of metabolic genes, was observed most clearly in microbes incubated at a temperature lower than that encountered in situ. On the other hand, decreases in the diversity of utilizable $C$ sources upon exposure to phages may have been due to lytic activity in which susceptible bacterial populations were differentially reduced by infective viruses, consistent with the "killing the winner" hypothesis. Treatment of cultures with MC-treated culture extracts, assumed to increase exposure to excised prophages, resulted in higher average metabolic rates after $18 \mathrm{~h}$, but lower rates after $48 \mathrm{~h}$ of incubation. With incubation at in situ temperature, this same treatment led to an initial increase in the number of readily utilized $C$ sources, followed by a decrease in community metabolic diversity relative to controls in samples from both hot springs. Thus, treatments designed to increase the interaction between hot spring microbes and either free or newly-excised phages had observable time- and temperature-dependent effects on community metabolism, demonstrating an important, yet complex, ecological role for phages in hot spring waters.
\end{abstract}

\section{Keywords}

Hot Springs, Virus, Prophage, Thermophiles, Carbon Metabolism 


\section{Introduction}

The term phages as used here refers specifically to bacteriophages and archaeal viruses, a subset of unicellular-organism parasites (UOPs, [1]). Although it is generally accepted that phages are key players in aquatic food webs and can influence bacterial diversity [2], relatively little is known regarding to what extent phages influence ecosystem function in extremely high-temperature environments such as hot springs. Recent work shows that deep-sea hydrothermal vents harbor diverse viral communities where incidences of lysogeny, and thus the density of temperate phages, may be quite high ([3] and cits. therein). Some of these deep-sea hydrothermal phages harbor auxiliary metabolic genes which alter the enzymatic capabilities of their host organisms [4]. Phages may be of importance as vectors for genetic exchange in terrestrial hydrothermal systems, yet little is known about specific impacts of either free or temperate phage on high-temperature bacterial community metabolism.

Thermal tolerance of phages and their ecological role are matters of interest because they represent the simplest particles possessing the fundamental properties of life as they occur under the sorts of hyperthermal conditions thought to have existed at the initiation of the Archaean eon (e.g., [5]), when it is believed life on Earth first originated. The coat proteins of some hot spring viruses suggest that some viruses may have a common viral ancestor that existed prior to life's differentiation into the three major domains [6] [7]. In addition, there are exobiological implications for information regarding phages from hot springs. Extreme thermal tolerance is likely to be de rigeur for life forms potentially encountered beyond Earth, so it will be useful to characterize viral assemblages from environments that are thermally extreme.

Past work has indicated that bacteriophages can be abundant in some hot springs, often reaching densities above $10^{6} \mathrm{~mL}^{-1}$ [8]. Phages are actively produced in hot springs, and in the springs thus far investigated, their lytic activity appears to have a significant impact on microbial community structure and energy flow [8]. Breitbart et al. [8] estimated that something in the range of $1 \%$ to $9 \%$ of bacteria were carrying prophages at one of the same sites considered in the present study.

Given that phages are vehicles for lateral gene transfer in addition to being a source of bacterial lysis, they may differentially transfer particular metabolic genes thereby influencing community function. This may change community-level abilities with respect to what specific C sources can be actively catabolized by hot springs bacteria. Examining the effect of both free phages and phages excised from lysogens on bacterial function in hot springs was the main research goal. Perhaps these phages play a demonstrably important role in regulating the physiological capabilities of the thermal water microbial community as a whole.

An experiment was designed to assess the impact of viruses on $\mathrm{C}$ metabolism by hot spring bacteria from alkaline (Paoha Island) and circumneutral (Little Hot Creek) thermal waters. "Natural" bacterial assemblage C source utilization patterns were compared with those of induced (mitomycin-C [MC]) and virus-spiked bacterial assemblages. In the case of Little Hot Creek, $\mathrm{C}$ utilization patterns were examined at two different temperatures, with the expectation that lowering temperature would serve as an environmental stress, selecting against the in situ-dominant hyperthermophiles and leading to a reduction in the diversity of $\mathrm{C}$ sources utilized. It was also hypothesized that bacterial community diversity, with respect to sources of utilizable C, would be reduced upon exposure to both a) higher concentrations of potentially-lytic phages occurring naturally in the water, and b) excised prophages induced by the MC treatment. In addition, it was expected that both experimental treatments would lead to a reduction in overall metabolic activity in hot spring samples.

\section{Materials \& Methods}

\subsection{Sampling Sites}

Interactions between phages and their heterotrophic bacterial hosts were examined in samples obtained from two eastern California (CA) hot springs: 1) a hot spring located on the shoreline of Paoha Island in Mono Lake, and 2) a spring at Little Hot Creek within the Long Valley caldera (Figure 1). The Paoha Island (PI) hot spring flows from the southeast shoreline of the island into the colder waters of the alkaline and hypersaline Mono Lake. Investigators have previously demonstrated that Mono Lake itself contains an abundant and molecularly diverse viral assemblage displaying seasonal dynamics [9] [10]. The bacterioplankton of Mono Lake has also been characterized (e.g., [11] and cits. therein).

The second hot spring sampled was at Little Hot Creek within the Long Valley Caldera. The site where sam- 
ples were collected at Little Hot Creek has been previously described as Little Hot Creek site \#3 [8]. Throughout this paper this site is designated simply as LHC (Figure 2).

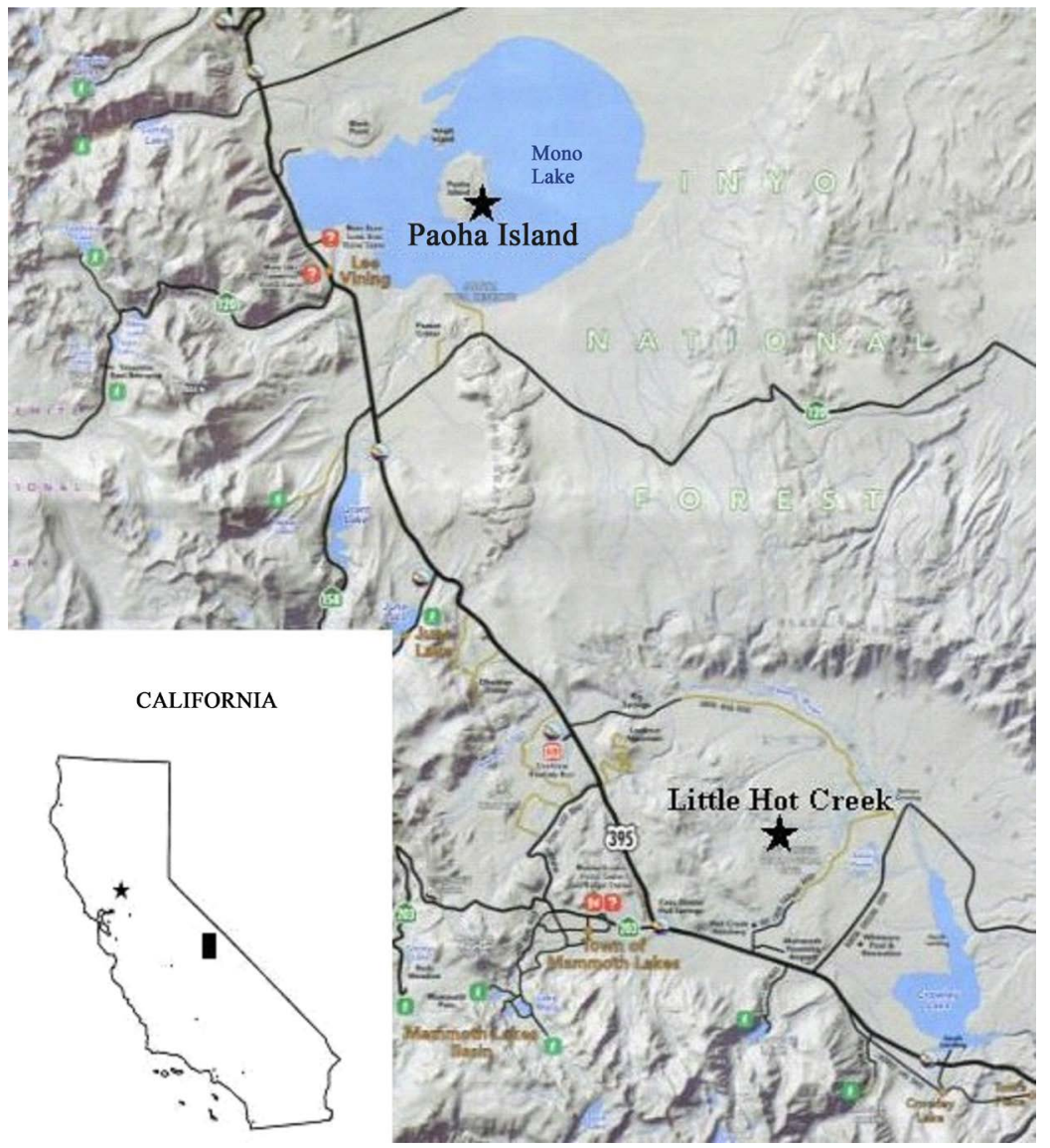

Figure 1. Regional map showing the two hot springs where samples were collected.

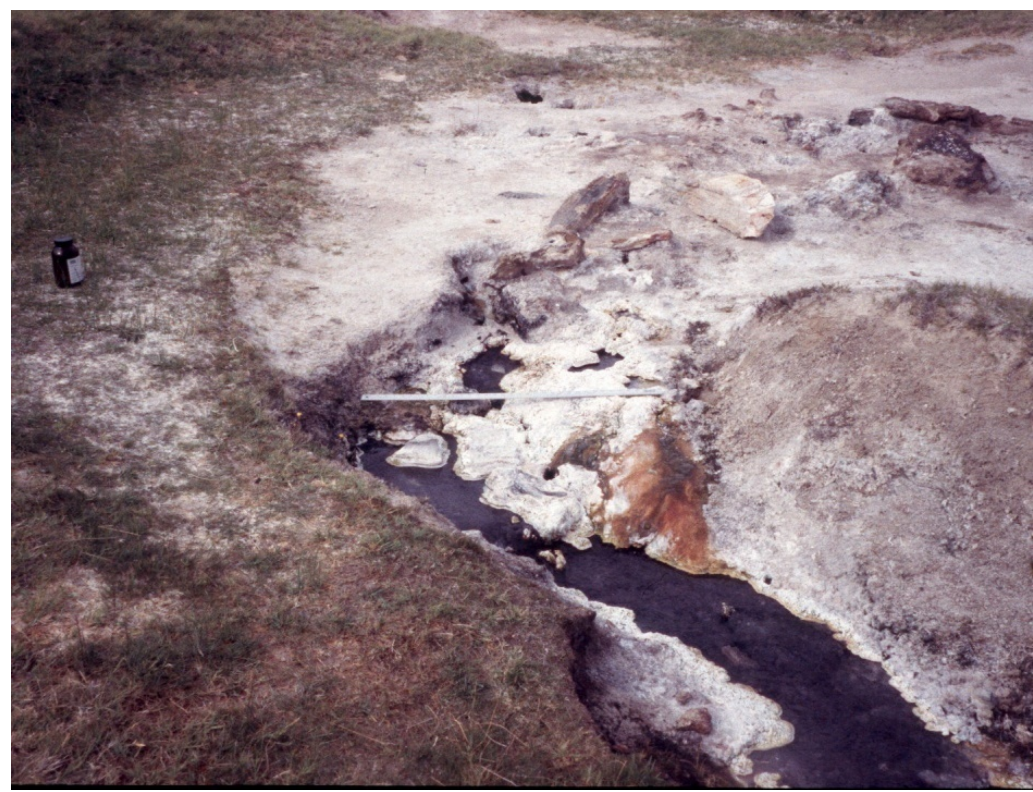

Figure 2. Little Hot Creek site (LHC) with meter stick shown for scale. 


\subsection{Water Quality}

Physicochemical attributes of hot spring waters were assessed using a HydroLab DataSonde ${ }^{\circledR} 4 a$ multiprobe. Measured parameters included: specific conductance $\left(\mathrm{mS} \cdot \mathrm{cm}^{-1}\right)$, salinity (ppt), $\mathrm{pH}$ (std. units), oxygen reduction potential $(\mathrm{mV})$, dissolved oxygen ( $\mathrm{mg} \cdot \mathrm{L}^{-1}$ ), turbidity (NTUs) and total dissolved solids $\left(\mathrm{g} \cdot \mathrm{L}^{-1}\right.$ ). Because of difficulty using the relatively large multiprobe in the narrow opening between rocks from which hot waters were flowing, the instrument had to be placed $0.1-0.2 \mathrm{~m}$ downstream of actual sample collection points. At PI, the multiprobe was used to test water just below the actual sample collection site. Thus, data other than the temperature data, reflect conditions at a point where hot spring waters were mixing to some unknown extent with Mono Lake water. Because it might more accurately reflect conditions in the thermal water proper, measurements of the large-volume (95-L), $0.2 \mu \mathrm{m}$-filtered water samples that were collected for viral work at PI were also made.

\subsection{Sample Collection and Virus Concentration}

At both hot spring sites 500-mL samples were collected. At the same time, smaller volume samples were preserved in 2\% EM-grade paraformaldehyde (pFMA). The virus size fraction > $30 \mathrm{kDa}$ was concentrated directly from hot springs by tangential-flow filtration (TFF) after first pumping approximately $95 \mathrm{~L}$ of hot spring water through a $0.22 \mu \mathrm{m}$ pore-size Opticap (Durapore PVDF pleated membrane) filter cartridge and into a large sterile container. A Pellicon 2 TFF system (Millipore Corp.) was used to concentrate viruses in this container. Two Pellicon ${ }^{\circledR} 2$ filter cartridges (regenerated cellulose, $30 \mathrm{kDa}$ molecular weight cut-off) were attached in series to the TFF system. The system was rinsed using $250 \mathrm{~mL}$ of $0.1 \mathrm{M} \mathrm{NaOH}$ and at least $1.0 \mathrm{~L}$ of $0.2 \mu \mathrm{m}$-filtered de-ionized water. The samples to be concentrated were run through the system using either a single- or double-headed Millipore Master-flex peristaltic pump at flow rates ranging from 300 to $600 \mathrm{~mL} \cdot \mathrm{min}^{-1}$ and a pressure of 20 psi.

When the samples were concentrated down to approximately $100 \mathrm{~mL}$, this retentate (i.e., sample concentrate) was collected into sterile, $500-\mathrm{mL}$ amber glass bottles. System washes were performed using 3 individual aliquots $(90-150 \mathrm{~mL}$ ) of TFF filter cartridge permeate. Each of the washes was collected separately and retentate, wash and permeate samples were refiltered through $0.1-\mu \mathrm{m}$ low protein binding polyethersulfone (PES) membrane filter units (Stericup ${ }^{\mathrm{TM}}$, Millipore Corp.) to remove any contaminating bacteria prior to sample transport. Small-volume 1 - 10-mL subsamples were preserved in pFMA.

Between samples the TFF system was cleaned using $500 \mathrm{~mL}$ of $0.1 \mathrm{M} \mathrm{NaOH}$ to destroy any infective phages remaining in the system and then rinsed with $2.0 \mathrm{~L}$ of the filtered de-ionized water to remove the $\mathrm{NaOH}$ from the system. The entire concentration and sample preservation procedure took approximately $3 \mathrm{~h}$ for each $95 \mathrm{~L}$ sample. The collected samples of retentate, washes, permeate and either preserved or unpreserved hot spring water were stored in the dark at ambient temperatures $\left(20^{\circ} \mathrm{C}-35^{\circ} \mathrm{C}\right)$ for approximately one week prior to further analyses.

\subsection{Enumeration of Virus-Like Particles (VLPs)}

VLPs in pFMA-preserved whole water, as well as in TFF retentate, wash and permeate, were determined by direct epifluorescent microscopic counts (EMC) following SYBR-Gold (Molecular Probes, Inc.) staining [12]. Samples were stained in filter funnels for $15 \mathrm{~min}$ and filtered onto $0.02 \mu \mathrm{m}$ Anodisc $25^{\circledR}$ (Whatman) filters using a technique similar to that of Noble \& Fuhrman [13]. Triplicate filters were prepared for each sample and were placed individually on glass microslides with SlowFade ${ }^{\circledR}$ Light antifade reagent (Molecular Probes, Inc.). They were examined using epifluorescence microscopy at $\times 1000$ and at least 400 VLPs were counted on each slide.

\subsection{Prophage Induction}

Prophage in 20-mL subsamples of whole hot spring water from both PI and LHC were induced by addition of 2 $\mu \mathrm{g} \cdot \mathrm{mL}^{-1} \mathrm{MC}$ while waters were held at $70^{\circ} \mathrm{C}$. After $16 \mathrm{~h}$ of $\mathrm{MC}$ exposure, samples were aseptically homogenized using a handheld Tissue Tearor ${ }^{\mathrm{TM}}$ (Biospec Products, Inc.) at medium speed for 5 sec. The two samples were then filtered through $0.45 \mu \mathrm{m}$ low protein-binding PVDF syringe filters for use as an inoculum in C utilization assays.

\subsection{Carbon Utilization Assays}

BiOLOG EcoPlates ${ }^{\mathrm{TM}}$ containing 31 different C sources (in triplicate wells) were used for community-level 
physiological profiling (CLPP). Individual EcoPlates ${ }^{\mathrm{TM}}$ were set up with: a) untreated “natural” water samples, b) water samples spiked with MC-induced sample extracts (called Treatment $M$ ), and c) water samples spiked with viral concentrate (i.e., TFF retentate) to increase viral density approximately 100-fold (called Treatment $R$, for retentate). There is no experimental replication beyond the level of the triplicate microwells for each $\mathrm{C}$ source. EcoPlates ${ }^{\mathrm{TM}}$ inoculated with LHC water were incubated at both $80^{\circ} \mathrm{C}$ and $35^{\circ} \mathrm{C}$, while PI samples were only incubated at $80^{\circ} \mathrm{C}$.

EcoPlates ${ }^{\mathrm{TM}}$ were read on a microplate reader (optical density @ $\left.750 \mathrm{~nm}\left[\mathrm{OD}_{750}\right]\right) 18$ and $48 \mathrm{~h}$ following inoculation, and specific changes in utilizable $\mathrm{C}$ sources were noted. Raw absorbance values were blanked against the control wells in each microplate and negative values were then considered to be 0 . Sole $\mathrm{C}$ source utilization was scored as high $\left(\mathrm{OD}_{750}>0.200\right)$, moderate $\left(0.150<\mathrm{OD}_{750}>0.200\right)$, low $\left(0.100<\mathrm{OD}_{750}>0.150\right)$, or negligible $\left(\mathrm{OD}_{750}<0.100\right)$. Average metabolic response (AMR), a measure of the catabolism of the various $\mathrm{C}$ sources present in the EcoPlates ${ }^{\mathrm{TM}}$, was calculated by averaging the mean difference between the average $\mathrm{OD}_{750}$ of the triplicate control wells and each of the C-source-containing wells. The triplicate blanked response values for each $\mathrm{C}$ source of each EcoPlate ${ }^{\mathrm{TM}}$ were averaged prior to principal components analysis (PCA) which was performed on both 18 and $48 \mathrm{~h}$ readings from EcoPlates ${ }^{\mathrm{TM}}$ based on the correlation matrix. PCA was performed using the SPSS v. 12.0.1 software package.

\subsection{Metabolic Phenotype Class "Winners" and "Losers"}

Recent work has attempted to reconcile observations with theoretical predictions regarding the impact of lytic phage on prokaryotic diversity. The kill-the-winner concept [14]-[16]; reviewed in [17] is essentially a predator-prey-type model mapped over to aquatic prokaryote-phage interactions in which "winners" are bacteria in a particular population or subpopulation that reach a sufficiently high density that they are then subject to a significant decrease in numbers due to the action of lytic phage. Theoretically then, winners invariably become losers. It has further been suggested that host-phage coexistence is regulated by fluctuations between host subpopulations having different viral susceptibility regions on cell surfaces which are reflected in diverse microbial genomes below the species level [18]. This view is supported by some excellent empirical work showing that sensitive host strains (not species) are killed off by lytic phage and replaced by phage-resistant strains of the same species [19]. Thus kill-the-winner dynamics do occur, but at a finer taxonomic scale than the single-species population.

In the present work, species, strains, or other traditional taxonomic groupings of hosts are neither defined nor identified. Rather, metabolic phenotype classes (MPCs) are operationally defined and these are classified as either winners or losers. For purposes of this discussion, any strain, population or multipopulation consortium of hot spring bacteria with a demonstrated ability to utilize a particular individual C source will be considered to be a "winner." Here a "winning" metabolic phenotype class (MPC) is operationally defined as any group of bacteria yielding an $\mathrm{OD}_{750}>0.100$ for a particular sole $\mathrm{C}$ source. "Losers" are operationally defined as MPCs yielding an $\mathrm{OD}_{750}<0.100$. "Winners" will be considered "killed" if a particular experimental treatment yields an $\mathrm{OD}_{750}$ less than $50 \%$ of that observed in untreated samples. Conversely, "winners" or "losers" will be considered to be "helped" if the experimental treatment results in an $\mathrm{OD}_{750}$ more than $50 \%$ greater that observed in untreated samples.

\section{Results}

\subsection{Hot Spring Water Quality}

Water temperatures at the PI and LHC sites were $87^{\circ} \mathrm{C}$ and $82^{\circ} \mathrm{C}$, respectively. General water quality characteristics differed greatly between the two sampled hot springs (Table 1). The waters at the PI site were alkaline and of higher salinity than at LHC. Higher dissolved $\mathrm{O}_{2}$, higher salinity, higher total dissolved solids, and higher $\mathrm{pH}$ at PI likely reflect some mixing of hot spring and open Mono Lake waters where the multiprobe was positioned. The major differences between the two sites are that LHC is circumneutral and low in dissolved ions, while the PI site is an alkaline hot spring, high in dissolved ions.

\subsection{VLP Densities}

VLPs were observed in both of the sampled hot springs following SYBR Gold staining. There were significantly 
Table 1. Sampling dates, site locations and water quality data from the two sampled hot springs. Values other than temperature data represent conditions 0.1 to $0.2 \mathrm{~m}$ downstream from outflow sources where samples were actually collected for other analyses. Numbers in parentheses are for $0.2 \mu \mathrm{m}$-filtered water following collection.

\begin{tabular}{ccc}
\hline & Paoha Island & Little Hot Creek \\
\hline sampling date & $6 / 23 / 2004$ & $6 / 24 / 2004$ \\
GPS Coordinates & N37 $59.649^{\prime}$ W119 $01.329^{\prime}$ & N37 $^{\circ} 41.435^{\prime}$ W118 $50.668^{\prime}$ \\
temperature $\left({ }^{\circ} \mathrm{C}\right)$ & $87(60-85)$ & 82 \\
specific conductance $\left(\mathrm{mS} \cdot \mathrm{cm}^{-1}\right)$ & $57.5(36.8)$ & 2.7 \\
salinity (ppt) & $37.8(22.6)$ & 6.9 \\
$\mathrm{pH}($ std. units) & $8.6(8.2)$ & 1.4 \\
oxygen reduction potential $(\mathrm{mV})$ & $57(111)$ & 0.81 \\
dissolved oxygen $\left(\mathrm{mg} \cdot \mathrm{L}^{-1}\right)$ & $2.15(0.45)$ & $<1.0$ \\
turbidity (NTUs) & $<1.0(<1.0)$ & 1.7 \\
\hline
\end{tabular}

Table 2. Density of VLPs in water samples, viral concentrates (i.e., TFF retentates) and the mean viral recovery efficiency of the TFF system as determined by EMC. VLP densities are means \pm 1 std. dev. for triplicate SYBR Gold-stained filters.

\begin{tabular}{cccc}
\hline Sample Site & Water VLP $\left.\mathbf{~ m L}^{-\mathbf{1}} \mathbf{( 1 0}^{\mathbf{5}}\right)$ & Retentate $\left.\mathbf{V L P} \mathbf{~ m L}^{-\mathbf{1}} \mathbf{( 1 0 ^ { 5 }}\right)$ & Recovery efficiency $\mathbf{( \% )}$ \\
\hline Little Hot Creek (LHC) & $1.74 \pm 1.46$ & $669.4 \pm 212.1$ & 63.3 \\
Paoha Island (PI) & $0.14 \pm 0.05$ & $66.0 \pm 39.9$ & 74.4 \\
\hline
\end{tabular}

fewer viruses in the PI hot spring than at LHC (Table 2). The employed TFF system effectively concentrated hot spring samples by approximately 1000 -fold while yielding relatively good recovery efficiencies with respect to VLPs (Table 2).

\subsection{Community-Level Physiological Profiles (CLPPs)}

Carbon Utilization Patterns in Control: BiOLOG EcoPlates ${ }^{\mathrm{TM}}$ containing 31 different $\mathrm{C}$ sources can be used to obtain a community fingerprint following inoculation with a mixed culture of microorganisms [20]. Carbon source utilization in EcoPlates ${ }^{\mathrm{TM}}$ was used as a means of obtaining CLPPs as has been done previously, for example, to monitor changes due to environmental impacts [21] [22].

Five of the $31 \mathrm{C}$ substrates were not metabolized by hot spring bacterial communities under any conditions. These unutilized C sources included: D, L- $\alpha$-glycerol phosphate, D-galactonic acid $\gamma$-lactone, D-malic acid, L-arginine, and L-threonine. The most rapidly metabolized substrate for both PI and LHC communities was the carboxylic acid, $\gamma$-hydroxybutyric acid (GHB). Based on EcoPlate ${ }^{\mathrm{TM}}$ assays conducted after $18 \mathrm{~h}$ at $80^{\circ} \mathrm{C}$, the untreated bacterial communities from PI and LHC highly used 6 and 5 different C sources, respectively, while the LHC community incubated at $35^{\circ} \mathrm{C}$ highly used only 1 of the 31 available $\mathrm{C}$ sources (Figure 3). After $48 \mathrm{~h}$ at $80^{\circ} \mathrm{C}$ the untreated bacterial communities from both PI and LHC utilized 2 additional C sources while that from LHC held at $35^{\circ} \mathrm{C}$ showed no metabolic diversification and used a total of 12 different $\mathrm{C}$ sources.

The Effect of Temperature on LHC Bacterial Metabolism: Metabolic diversity of the untreated LHC community was greatly reduced at lower temperature. Of the 31 sole $\mathrm{C}$ sources, only GHB was utilizable by the natural community at $35^{\circ} \mathrm{C}$ after both 18 and $48 \mathrm{~h}$. At $80^{\circ} \mathrm{C}$, a temperature closer to the ambient hot spring temperature, $3 \mathrm{C}$ sources were utilized at low levels (Tween $80, \alpha$-cyclodextrin and D-glucosaminic acid) and 2 were used at moderate levels (D-mannitol and GHB) within $18 \mathrm{~h}$. Thus LHC bacteria appear to be metabolically stressed at $35^{\circ} \mathrm{C}$, but still able to metabolize GHB, a short-chain fatty acid metabolite of $\gamma$-aminobutyric acid [GABA]. Both treated and untreated PI bacteria also utilized GHB at high levels at $80^{\circ} \mathrm{C}$.

Overall metabolic rate of the untreated LHC community was greatly reduced at the lower temperature. In untreated LHC samples average metabolic response (AMR) was decreased by nearly an order of magnitude at $35^{\circ} \mathrm{C}$ (Figure 4). AMR was also much lower at $35^{\circ} \mathrm{C}$ than at $80^{\circ} \mathrm{C}$ for samples spiked with MC induced sample extracts (Treatment $M$, Figure 4). Most interestingly, following $48 \mathrm{~h}$ of incubation, the AMR of the samples spiked with viral concentrate (Treatment $R$ ) and incubated at $35^{\circ} \mathrm{C}$ was even higher than that of the samples incubated at $80^{\circ} \mathrm{C}$ (Figure 4). 


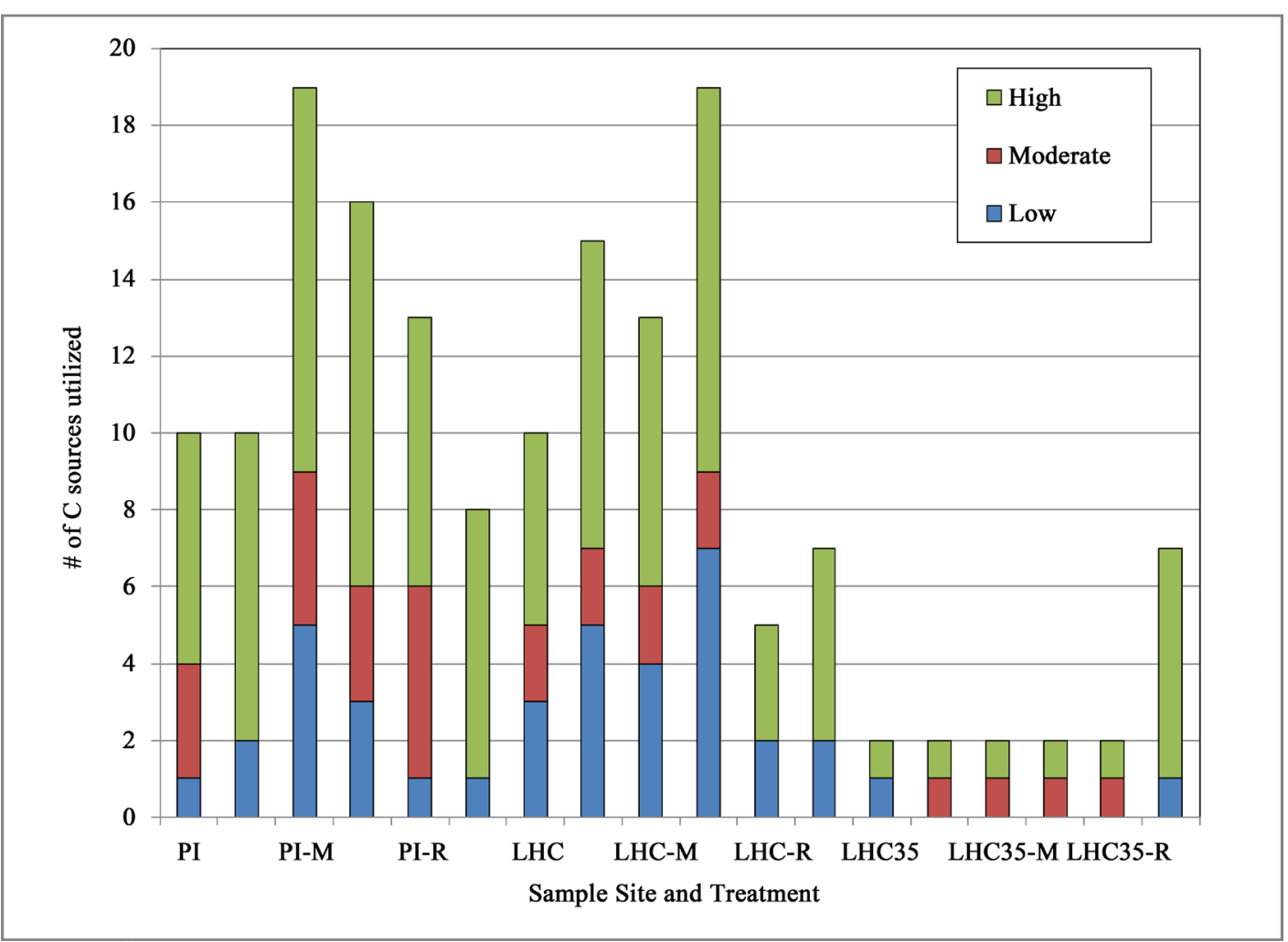

Figure 3. Total numbers of individual $\mathrm{C}$ sources utilized by hot spring microbial communities at $80^{\circ} \mathrm{C}$ (or $35^{\circ} \mathrm{C}$ in case of LHC35), along with level of utilization (either High $\left(\mathrm{OD}_{750}>0.200\right)$, Moderate $\left(0.150<\mathrm{OD}_{750}>0.200\right)$, or Low $(0.100<$ $\left.\mathrm{OD}_{750}>0.150\right)$ under various treatments. Two sets of data for each site-treatment combination are presented with the stacked bar on the left representing data after $18 \mathrm{~h}$ and the one on the right after $48 \mathrm{~h}$.

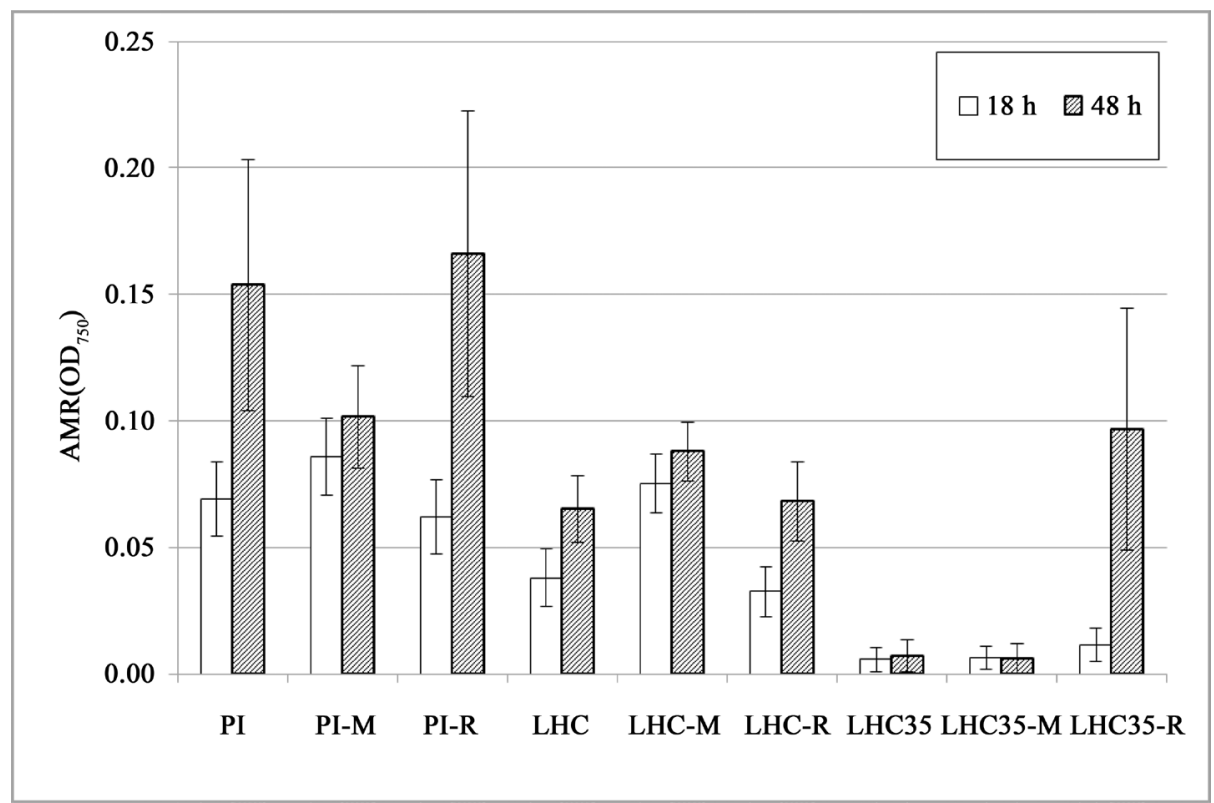

Figure 4. Bacterial community metabolic activity expressed as average metabolic response (AMR \pm 1 SEM) for samples from Paoha Island (PI) and Little Hot Creek (LHC) hot springs after two different incubation times. LHC samples incubated at $35^{\circ} \mathrm{C}$ are labeled "LHC35" while all other samples were incubated at $80^{\circ} \mathrm{C}$. Bars labeled with " $M$ " or " $R$ " correspond to results from treatments $M$ and $R$ as described above. 
Growth temperature clearly had an impact on community-level physiological profiles (CLPPs) of LHC bacteria. After $18 \mathrm{~h}$ of incubation, bacteria grown at $35^{\circ} \mathrm{C}$ had virtually indistinguishable CLPPs regardless of experimental treatment, while, within the same time period, those grown at $80^{\circ} \mathrm{C}$ displayed greater variability (Figure 5). Also, incubation temperature appeared to play a role in relative degree of CLPP response of LHC bacteria to Treatment $R$ following the full $48 \mathrm{~h}$ period of incubation (Figure 5).

The Effect of Increasing Free Phage Concentration: Addition of TFF retentate to EcoPlates ${ }^{\mathrm{TM}}$ is estimated to have increased free phage (i.e., VLP) densities by between 50 and 100-fold. Adding phage-size-fraction concentrate to LHC water (Treatment $R$ ) and incubating at $80^{\circ} \mathrm{C}$ for $18 \mathrm{~h}$ reduced the total number of highly utilized C sources from 5 to 3 (Figure 3). Substrates utilized by LHC controls within $18 \mathrm{~h}$, but which were not used by the Treatment $R$ community were D-mannitol, $\alpha$-cyclodextrin, D-glucosaminic acid and Tween 80, while Treatment $R$ appeared to confer an increased ability to metabolize D-xylose and phenylethylamine The PI bacterial community was generally unaffected by phage concentrate (Figure 3 \& Figure 4) with the exception of an acquired ability to catabolize L-serine at moderate levels following phage concentrate addition. Thus the untreated PI community utilized a total of 6 sole C sources and the retentate/concentrate-amended community utilized 7 sources. Interestingly, amendment with phage concentrate decreased metabolic diversity observed after both 18 and $48 \mathrm{~h}$ in LHC water, but had less impact in PI water (Figure 3).

In terms of the effect on AMR of spiking samples with free viral concentrate (Treatment $R$ ), responses varied with hot spring tested and, in the case of LHC, with temperature of incubation. Adding viral concentrate had little impact on AMR of the PI and LHC samples held at $80^{\circ} \mathrm{C}$, but greatly increased AMR in LHC samples incubated at $35^{\circ} \mathrm{C}$, particularly after $48 \mathrm{~h}$ (Figure 4).

The dramatic change in both the AMR \& CLPP between 18 and $48 \mathrm{~h}$ of LHC bacteria spiked with viral concentrate and incubated at $35^{\circ} \mathrm{C}$, was the most unexpected result of the study (Figure $4 \&$ Figure 5). Relative to controls, this treatment $(R)$ greatly increased overall community respiration as well as the number of $\mathrm{C}$ sources

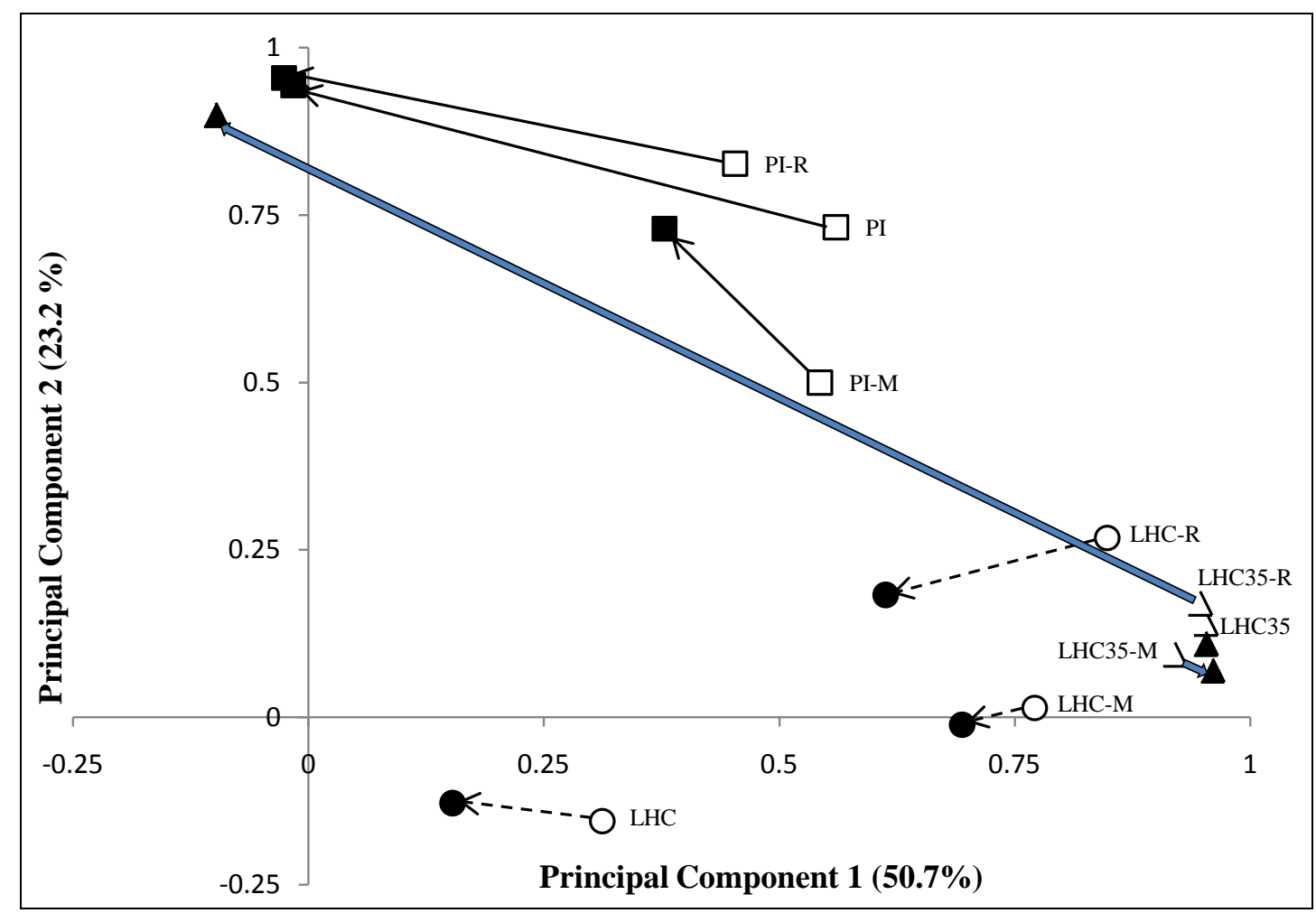

Figure 5. PCA of CLPP for PI (“ $\square$ ”) and LHC (“०” for $80^{\circ} \mathrm{C}$ and " $\Delta$ ” for $35^{\circ} \mathrm{C}$ incubation) hot spring bacterial communities subjected to different experimental treatments. Points labeled with " $\mathrm{M}$ " or "R" correspond to results from treatments $M$ and $R$ as described above, while others are untreated controls. Arrows connect data after $18 \mathrm{~h}$ (open symbols) to data collected after $48 \mathrm{~h}$ (solid symbols) of incubation. Levels of variation explained by individual principal components are in parentheses on axes titles. 
utilized, particularly after $48 \mathrm{~h}$. The large change in C source utilization pattern of the $\mathrm{LHC} 35^{\circ} \mathrm{C}$ assemblage in response to Treatment $R$ after $48 \mathrm{~h}$, relative to minor changes in the untreated control and excised prophage-spiked sample (Treatment $M$ ) is evident in the PCA plot (Figure 5).

Addition of phage to the PI sample killed 1 of 8 winners, helped 2 of 8 winners and helped 1 loser after 48 h. Addition of free phage to the LHC sample killed 6 of 8 MPC winners, helped no winners and helped 1 loser after $48 \mathrm{~h}$ at $80^{\circ} \mathrm{C}$ by apparently conferring an ability to metabolize D-xylose. Addition of phage to the LHC sample that was incubated at only $35^{\circ} \mathrm{C}$ neither killed nor helped the only winner present in untreated controls (i.e., the MPC utilizing GHB), however, this treatment did help 5 of 30 losers.

The Effect of Adding Excised Prophage: The addition of MC-treated whole water extract theoretically added phages newly excised from lysogens to the natural hot spring communities relative to untreated controls. In both LHC and PI samples this treatment increased the metabolic diversity observed within 18 h (Figure 3). For example, the LHC community utilized neither Tween 40, glucose-1-phosphate, L-phenyalanine, nor glycyl-Lglutamic acid in detectable quantities when left untreated, but did utilize these substrates to varying degrees when supplemented with the MC-treatment extract. Also, degrees of GHB utilization were enhanced by roughly $12 \%$ and $40 \%$ following addition of MC extracts in PI and LHC waters respectively.

Spiking samples with MC-induced sample extracts (Treatment $M$ ) actually led to higher AMRs after $18 \mathrm{~h}$ in both PI and LHC samples held at $80^{\circ} \mathrm{C}$ but had no effect on LHC bacteria at the $35^{\circ} \mathrm{C}$ incubation temperature (Figure 4). The relatively large increases in AMRs occurring between 18 and $48 \mathrm{~h}$ in untreated control and Treatment $R$ samples were not observed in Treatment $M$ samples (Figure 4).

After the initial $18 \mathrm{~h}$ of incubation of PI microbes, Treatment $M$ had a somewhat greater impact on the CLPP than Treatment $R$, though after $48 \mathrm{~h}$, CLPPs of treated and control samples tended to converge (Figure 5). Treatment $M$ had somewhat less of an impact than Treatment $R$ on CLPP in the $80^{\circ} \mathrm{C}$ incubation and, based on comparison to the control, had virtually no impact whatsoever on the samples incubated at only $35^{\circ} \mathrm{C}$ (Figure 5 ). As in controls, LHC Treatment $M$ bacteria incubated at $35^{\circ} \mathrm{C}$ utilized GHB, and this only at a low rate.

Addition of induced prophage to the PI sample killed 3 of 8 MPC winners, helped no winners, but helped 3 losers after $48 \mathrm{~h}$. Addition of induced prophage to the LHC sample killed 1 of 8 winners, helped no winners and helped 2 losers after $48 \mathrm{~h}$ at $80^{\circ} \mathrm{C}$. Addition of phage to the LHC sample that was then incubated at only $35^{\circ} \mathrm{C}$ neither killed nor helped the GHB-utilizing winner present in untreated controls, nor did it help any of the 25 losers.

\section{Discussion}

\subsection{Methodological Considerations}

The VLP density obtained at the PI hot spring was 2 to 3 orders of magnitude less than those previously obtained in the open waters of Mono Lake, which are among the highest viral concentrations in an aquatic system yet observed [9]. VLP abundances observed in this study are similar to that obtained at the mildly alkaline $(\mathrm{pH}=$ 8.1) Octopus hot spring in Yellowstone National Park [23]. The number of VLPs observed at LHC was roughly half that obtained by investigators who sampled the same site in July 2001 and one-quarter that obtained in July 2002 [8]. Lower LHC VLP counts relative to those found by Breitbart et al. [8] could be due to differences in staining methods. Different concentration of SYBR-Gold, different durations of staining, or other differences in sample preparation techniques could account for differences. Alternatively, lower counts in the present study could actually be due to natural environmental variability over time. A 6.5-fold difference in VLP counts was observed at the Casa Diablo hot spring for two samples collected approximately one year apart [8]. Within the span of a year, the number of host cells may have decreased due to environmental changes, thereby changing the reproductive rate or survivability of viruses. In fact, without replicate counts, it cannot be known with certainty whether the LHC VLP densities reported here are significantly lower than those obtained by Breitbart et al. [8].

It is now known that standard aldehyde preservation of water samples, as was done here, can lead to significant underestimates of virus densities even when samples are stored for only a few weeks [24]. Sample deterioration may partially account for the relatively large variability in VLP counts from our replicate SYBR-Gold preparations (Table 1). However, given that both Breitbart et al. [8] and Jiang et al. [9] preserved their samples in 2\% pFMA and 1\% FMA respectively, differences in the VLP counts obtained in this study and these earlier studies likely reflect actual differences in VLP densities. Thus, in the case of LHC, VLP densities appear to change through time. That PI hot spring water would have a viral density much different from that of the cooler, 
open water of Mono Lake into which it flows is expected.

This study did not directly assess the effectiveness of MC treatment on inducing prophages, however it was previously found that MC treatment increased the number of VLP from 1.2 to 1.4-fold at LHC sites [8]. This suggests that phage excision from lysogens likely resulted from MC treatment in the present study as well. Of course it is quite possible that some populations of lysogens within our samples were not sensitive to MC treatment. There is likely to be a great deal of variability in the amount of MC exposure time needed for induction. The duration of exposure utilized in this study $(16 \mathrm{~h})$ was intermediate relative to that utilized in other studies. For example, largest increases in viral abundance occur after $24 \mathrm{~h}$ of MC exposure in samples from Lake Superior [25], and $24 \mathrm{~h}$ of exposure resulted in MC-inducible prophage in hydrothermal vent waters [3]. On the other hand, other investigators utilize much shorter MC exposure times. In one case, MC exposure for only 30 min gave the largest induction responses from cultivated lysogenic bacteria [26]. The $16 \mathrm{~h}$ of MC exposure used to prepare our excised phage-enriched extract was likely to be sufficient in duration.

Since MC is a mutagen, an additional concern in studies of this type is direct effects of MC on bacterial function unrelated to prophage excision. A previous study found that the amount of MC added to culture media was reduced by $29 \%$ after $30 \mathrm{~min}$ and by $53 \%$ after $60 \mathrm{~min}$ of incubation [27], yet, to my knowledge, nothing is known regarding the stability of MC in natural water samples. Since MC was not added directly to EcoPlates ${ }^{\mathrm{TM}}$, but rather MC-induced sample extracts, and since a relatively long MC exposure time was chosen, the likelihood of direct toxic effects of MC on native bacteria was minimized to as great an extent as possible.

It should further be emphasized that this investigation deals with only a select subset of metabolic processes engaged in by hot spring bacteria at these sites. Any obligate anaerobes in hot spring samples would probably not have survived the methodological process used herein because samples were exposed to atmospheric $\mathrm{O}_{2}$ at several steps during both prophage induction and C utilization assays themselves. Therefore CLPP was directed at $\mathrm{C}$ utilization by aerobes, facultative anaerobes, or microaerophiles. The proportions of the native prokaryotic community which fall into each of these $\mathrm{O}_{2}$-tolerance classes in the waters sampled from these hot springs is unknown.

\subsection{Effects of Treatments on Community-Level Physiological Profiles CLPPs}

It appears that lysogenic phage excised in response to MC addition did not reduce the overall metabolic capacities of the bacterial assemblages from either PI or LHC hot springs. Despite initial $(18 \mathrm{~h})$ increases in AMR relative to controls in samples incubated at $80^{\circ} \mathrm{C}$, after $48 \mathrm{~h}$ the AMR for Treatment $M$ was, averaged over all sample types, within $5 \%$ of that in untreated controls. Exposure of hot spring samples to MC-induced sample extracts did increase the number of utilized C sources (Figure 3), but without increasing overall respiration (i.e., AMR). Studies from marine systems indicate that temperate phage may exert a strong influence on bacterial diversity (e.g., [28]) and it is generally accepted that both lytic and lysogenic phage are capable of influencing bacterial diversity [1] [29]. Such changes in diversity could clearly impact metabolic capabilities of bacterial assemblages as a whole. An additional impact of MC-induced sample extract addition was a reduction in the degree of change in AMR which occurred between 18 and $48 \mathrm{~h}$, relative to both control and Treatment $R$ samples.

Although specific effects of phage on microbial community $\mathrm{C}$ metabolism have been observed in this study, it is important to note that effects may vary in samples collected at different times, even over periods of short duration. Several studies have shown that virioplankton populations are highly dynamic. For example, main targets of viral infection in waters of the North Sea appear to change on time scales of days or even hours [30]. Virioplankton in marine systems may be highly variable over short time spans, but viruses in hot springs may also be highly dynamic. For example Breitbart et al. [8] observed a phage population turnover time of 1.2 days at the same LHC site as considered herein, and these same authors also observed that phage-mediated mortality accounted for a significant proportion (>25\%) of microbial community production at their nearby LHC-4 site. As mentioned above, VLP density itself appears to fluctuate from year to year at the same hot spring site.

The major decrease in AMR for untreated samples incubated at a reduced temperature $\left(35^{\circ} \mathrm{C}\right.$ as opposed to $80^{\circ} \mathrm{C}$ ) is consistent with prior work demonstrating that hot spring microbial communities are adapted for growth at higher temperatures. For example Breitbart et al. [8] found that Imperial Spa hot spring prokaryotic production was $86 \%$ lower when they were grown at $39^{\circ} \mathrm{C}$ than at $66^{\circ} \mathrm{C}$. Bacteria found at different temperatures along thermal gradients have metabolic temperature optima which reflect their environmental temperatures (e.g., [31]). In the present study, temperature had an impact not only on responses of the LHC control but also on the great 
difference in response to the spiking of LHC samples with phage concentrate (Treatment $R$ ).

Loss of the capacity of LHC bacteria to catabolize either D-mannitol or Tween 80 after $18 \mathrm{~h}$ following the addition of phage concentrate may indicate the loss of one or more physiological types due to viral lysis. Prior work in marine systems has shown that some bacterial and archaeal operational taxonomic units (OTUs) virtually disappear in response to virus amendment [32]. It is logical that loss of particular metabolic capabilities within a bacterial assemblage would go hand-in-hand with loss of particular OTUs.

Although bacterial population growth rate was not assessed in the current study, it seems reasonable to conclude that observed changes in $\mathrm{C}$ source usage patterns accompanying viral concentrate addition are reflective of changes in bacterial community composition of the type observed in other studies. For example, a prior study with lake water samples has shown that bacterial communities incubated with and without the viral community from the same sample resulted in changes in the abundance and growth rates of bacterial populations as well as in changes in community composition [33].

\subsection{Phage in Hot Springs: Win, Lose or Draw?}

The idea of lytic phage "killing the winner" [15] [16] is the increasingly accepted idea that lytic viruses can keep competitive dominants in check and thus are critical for sustaining bacterial diversity by allowing less competitive taxa to thrive when dominants are lysed. The lysis of dominant taxa theoretically allows for competitive release (sensu Connell [34]), i.e., when one or more competing species or strains being removed from a habitat, release one or more of the remaining species or strains from some factor(s) that had previously limited its(their) population size(s). Perhaps another way that this could happen is through host cell lysis leading to changes in dissolved organic matter (DOM) composition and/or availability. It has already been concluded that experimentally manipulating phage abundance (e.g., by adding viral concentrates) can lead to changes in bacterial abundance, production, respiration, enzymatic activity and the composition of both dissolved and particulate organic matter pools [29]. Lytic phages also produce lysates rich in other potentially limiting nutrients such as phosphorus (P). For example, dissolved DNA from viral lysis has been shown to be an important compound in an aquatic P cycle [35]. Clearly viral lysis could increase P availability thereby favoring less competitive taxa. Thus, one scenario would be phage killing the winners and this going hand-in-hand with helping the losers. Phages helping maintain metabolic diversity of prokaryote assemblages is consistent with the maintenance of diversity resulting from the reduction of various subpopulations having differing viral susceptibilities previously proposed for marine systems [18].

It is clearly understood that phage-mediated horizontal gene transfer (e.g., via either generalized or specialized transduction) may change the metabolic capabilities of recipient cells. A classic example of this is the way in which phage-encoded genes control bacterial pathogenicity [36]. In the same way that phage can make bacteria better suited for infecting animal hosts, addition of either free viral concentrate or induced prophage can lead to assemblages better able to withstand stressful conditions in natural aquatic habitats. An example of such a stressful condition would be the lower than normal growth temperature used for LHC bacteria in this study. The implication is that losers would be helped only under particular environmental conditions. A second scenario can therefore be envisioned in which rare physiotypes are helped by the action of phages without the initial lysis of competitive dominants. In other words, losers can be helped without winners being killed.

It has been proposed that the prevalence of lysogenic bacteria will be higher under stressful environmental conditions [3] and the frequency of lysogeny has been shown in some cases to increase as C and energy availability decrease ([37] and cits. therein). Differences in the techniques used to estimate the prevalence of lysogeny in different studies, however make broad generalizations risky. A confounding problem is that the relative abundances and intensity of metabolic activities expressed by winners and losers vary strongly with level of environmental stress. For example, in this study, the induction of prophage at the cooler than normal temperature $\left(35^{\circ} \mathrm{C}\right)$ had a relatively minor impact compared to that at the in situ temperature with respect to $\mathrm{C}$ metabolism. Yet the main reason for this is the fact that there are so few winners with respect to $\mathrm{C}$ physiotypes at this lower temperature to begin with. Considering only untreated LHC controls after $48 \mathrm{~h}$ of incubation, there were 8 physiotype winners, i.e., 8 of the 31 available $\mathrm{C}$ sources were utilized $\left(\mathrm{OD}_{750}>0.100\right)$ at $80^{\circ} \mathrm{C}$, while only 1 winner of 31 was observed at $35^{\circ} \mathrm{C}$. In terms of metabolic capabilities, little wonder then that the likelihood of having losers helped under stressful conditions (in this case lower temperature) is increased. There are simply more losers to begin with in natural samples when those samples are placed under stressful conditions. 
Our data provide evidence for killing of the winner with respect to physiological classes of bacteria after $48 \mathrm{~h}$, but only when hot spring samples are maintained at the in situ temperature. Unexpectedly, physiotype losers were not particularly helped by free native phage or excised prophage addition except in the case of the communities maintained at $35^{\circ} \mathrm{C}$ when TFF retentate was added (Treatment $R$ ). Exposure of the LHC culture to this viral retentate, followed by growth at suboptimal temperature, decreased the fraction of overall winner metabolism associated with GHB catabolism. Whereas Treatment $R$ led to tremendous stimulation of overall metabolic rate in the LHC cultures grown at $35^{\circ} \mathrm{C}$, particularly after $48 \mathrm{~h}$; the breakdown of organics such as D-cellubiose, $\alpha$-D-lactose and N-acetyl-D-glucosamine became much more important relative to the GHB metabolism that dominated in both control and Treatment $M$ microplates. In fact, Treatment $M$ eliminated utilization of virtually every C source save GHB by LHC bacteria grown at the lower temperature. These findings support the idea that the ability of both free and induced phage to kill the winner(s), physiologically speaking, is dependent upon environmental factors that might lead to stress in the microbial community.

In this work, the effect of both lytic and lysogenic phages on bacterial function in hot springs was examined. The data from this study demonstrate for the first time that phages play a role in altering the CLPPs of hot spring bacteria. The nature of the change is both site and temperature-dependent. Hot spring CLPPs can change in response to both prophage induction and to addition of free phage. Whether perennial stability in prokaryotic phylotypes apparently observed in some thermal waters (e.g., [38]) reflects stability in the killing effect of lytic phage or a general lack of viral impact on host phylotype diversity in such habitats remains unknown. Perhaps CLPPs are to some extent independent of phylotype profiles. Even though it is known that various strains of bacteria of the same species have differing metabolic capabilities and that community fluctuations due to phage lysis occur at the finer grain of microbial strains rather than species [19], it will be unwise to equate our winning or losing MPCs with recognized taxonomic units (e.g., bacterial strains) or sequence-based OTUs.

Although the results obtained in this study may not be applicable to all thermal waters, they give a glimpse into the potential ecological importance of viruses from extreme thermal environments. Major advances have been made in understanding the diversity of phage genotypes in many sample types. The results reported above have added a tiny sketch of an answer to the question "What are they doing?" as an addition to our increasing knowledge of "Who's there?” with respect to phages in extreme thermal environments.

\section{Acknowledgements}

Thanks to Forest Rowher, Ken Stedman, Adam Clore, and Jennifer Brum for their assistance in the field. Special thanks go to Bob Jellison for providing access to Paoha Island in Mono Lake and to Grieg Steward for help in obtaining samples. Thanks also to Grieg Steward and Ken Stedman for their constructive comments on the manuscript. Travel support from the National Aeronautics and Space Administration's Astrobiology Institute is acknowledged, and this work was also supported by NASA’s Exobiology Program Grant No. NAG5-9889.

\section{References}

[1] Abedon, S.T. (2008) Phages, Ecology, Evolution. In: Abedon, S.T., Ed., Bacteriophage Ecology: Population Growth, Evolution, and Impact of Bacterial Viruses, Chap. 1, Cambridge University Press, Cambridge, 1-30. http://dx.doi.org/10.1017/CBO9780511541483.004

[2] Suttle, C.A. (2007) Marine Viruses-Major Players in the Global Ecosystem. Nature Reviews Microbiology, 5, 801812. http://dx.doi.org/10.1038/nrmicro1750

[3] Williamson, S.J., Cary, S.C., Williamson, K.E., Helton, R.R., Bench, S.R., Winget, D. and Wommack, K.E. (2008) Lysogenic Virus-Host Interactions Predominate at Deep-Sea Diffuse-Flow Hydrothermal Vents. The ISME Journal, 2, 1112-1121. http://dx.doi.org/10.1038/ismej.2008.73

[4] Anantharaman, A.K., Duhaime, M., Breier, K., Wendt, J., Toner, B. and Dick, G.J. (2014) Sulfur Oxidation Genes in Diverse Deep-Sea Viruses. Science, 344, 757-760.

[5] Ernst, W.G. (1983) The Early Earth and the Archaean Rock Record. In: Schopf, J.W., Ed., Earth's Earliest Biosphere, Its Origin and Evolution, Princeton University Press, Princeton, 41-52.

[6] Rice, G., Tang, L., Stedman, K., Roberto, F., Spuhler, J., Gillitzer, E., Johnson, J.E., Douglas, T. and Young, M. (2004) The Structure of a Thermophilic Archaeal Double-Stranded DNA Viral Capsid Type that Spans All Domains of Life. PNAS, 101, 7495-7496. http://dx.doi.org/10.1073/pnas.0401773101

[7] Maaty, W.S., Ortmann, A.C., Dlakić, M., Schulstad, K., Hilmer, J.K., Liepold, L., Weidenheft, B., Khayat, R., Douglas, 
T., Young, M.J. and Bothner, B. (2006) Characterization of the Archaeal Thermophile Sulfolobus Turreted Icosahedral Virus Validates an Evolutionary Link among Double-stranded DNA Viruses from All Domains of Life. Journal of Virology, 80, 7625-7635. http://dx.doi.org/10.1128/JVI.00522-06

[8] Breitbart, M., Wegley, L., Leeds, S., Schoenfeld, T. and Rowher, F. (2004) Phage Community Dynamics in Hot Springs. Applied and Environmental Microbiology, 70, 1633-1640. http://dx.doi.org/10.1128/AEM.70.3.1633-1640.2004

[9] Jiang, S., Steward, G., Jellison, R., Chu, W. and Choi, S. (2004) Abundance, Distribution, and Diversity of Viruses in Alkaline, Hypersaline Mono Lake, California. Microbial Ecology, 47, 9-17. http://dx.doi.org/10.1007/s00248-003-1023-X

[10] Sabet, S., Chu, W. and Jiang, S.C. (2006) Isolation and Genetic Analysis of Haloalkiliphilic Bacteriophages in a North American Soda Lake. Microbial Ecology, 51, 543-554. http://dx.doi.org/10.1007/s00248-006-9069-1

[11] Humayoun, S.B., Bano, N. and Hollibaugh, J.T. (2003) Depth Distribution of Microbial Diversity in Mono Lake, a Meromictic Soda Lake in California. Applied and Environmental Microbiology, 69, 1030-1042. http://dx.doi.org/10.1128/AEM.69.2.1030-1042.2003

[12] Chen, F., Lu, J., Binder, B., Liu, Y. and Hodgson, R. (2001) Application of Digital Image Analysis and Flow Cytometry to Enumerate Marine Viruses Stained with SYBR Gold. Applied and Environmental Microbiology, 67, 539-545. http://dx.doi.org/10.1128/AEM.67.2.539-545.2001

[13] Noble, R. and Fuhrman, J.A. (1998) Use of SYBR Green 1 for the Rapid Epifluorescence Counts of Marine Viruses and Bacteria. Aquatic Microbial Ecology, 14, 113-118. http://dx.doi.org/10.3354/ame014113

[14] Thingstad, T.F. (1997) A Theoretical Approach to Structuring Mechanisms in the Pelagic Food Web. Hydrobiologia, 363, 59-72. http://dx.doi.org/10.1023/A:1003146310365

[15] Thingstad, T.F. (2000) Elements of a Theory for the Mechanisms Controlling Abundance, Diversity, and Bio-Geochemical Role of Lytic Bacterial Viruses in aquatic Ecosystems. Limnology and Oceanography, 45, 1320-1328. http://dx.doi.org/10.4319/lo.2000.45.6.1320

[16] Thingstad, T.F. and Lignell, R. (1997) Theoretical Models for the Control of Bacterial Growth Rate, Abundance, Diversity and Carbon Demand. Aquatic Microbial Ecology, 13, 19-27. http://dx.doi.org/10.3354/ame013019

[17] Thingstad, T.F., Bratbak, G. and Heldal, M. (2008) Aquatic Phage Ecology. In: Abedon, S.T., Ed., Bacteriophage Ecology: Population Growth, Evolution, and Impact of Bacterial Viruses, Cambridge University Press, Cambridge, 251280. http://dx.doi.org/10.1017/CBO9780511541483.013

[18] Avrani, S., Schwartz, D.A. and Lindell, D. (2012) Virus-Host Swinging Party in the Oceans: Incorporating Biological Complexity into Paradigms of Antagonistic Coexistence. Mobile Genetic Elements, 2, 88-95. http://dx.doi.org/10.4161/mge.20031

[19] Rodriguez-Brito, B., Li, L.L., Wegley, L., Furlan, M., Angly, F., Breitbart, M., Buchanan, J., Desnues, C., Dinsdale, E., Edwards, R., Felts, B., Haynes, M., Liu, H., Lipson, D., Mahaffy, J., Martin-Cuadrado, A.B., Mira, A., Nulton, J., Pasić, L., Rayhawk, S., Rodriguez-Mueller, J., Rodriguez-Valera, F., Salamon, P., Srinagesh, S., Thingstad, T.F., Tran, T., Thurber, R.V., Willner, R., Youle, M. and Rohwer, F. (2010) Viral and Microbial Community Dynamics in Four Aquatic Environments. The ISME Journal, 4, 739-751. http://dx.doi.org/10.1038/ismej.2010.1

[20] Garland, J.L. and Mills, A.L. (1991) Classification and Characterization of Heterotrophic Microbial Communities on the Basis of Patterns of Community Level Sole Carbon-Source Utilization. Applied and Environmental Microbiology, 57, 2351-2359.

[21] Garland, J.L. (1997) Analysis and Interpretation of Community-Level Physiological Profiles in Microbial Ecology. FEMS Microbiology Ecology, 24, 289-300. http://dx.doi.org/10.1111/j.1574-6941.1997.tb00446.x

[22] Lehman, M.R., Colwell, F.S. and Garland, J.L. (1997) Physiological Profiling of Indigenous Aquatic Microbial Communities to Determine Toxic Effects of Metals. Environmental Toxicology and Chemistry, 16, 2232-2241. http://dx.doi.org/10.1002/etc.5620161106

[23] Schoenfeld, T., Patterson, M., Richardson, P.M., Wommack, K.E., Young, D. and Mead, D. (2008) Assembly of Viral Metagenomes from Yellowstone Hot Springs. Applied and Environmental Microbiology, 74, 4164-4174. http://dx.doi.org/10.1128/AEM.02598-07

[24] Wen, K., Ortmann, A.C. and Suttle, C.A. (2004) Accurate Estimation of Viral Abundance by Epifluorescence Microscopy. Applied and Environmental Microbiology, 70, 3862-3867. http://dx.doi.org/10.1128/AEM.70.7.3862-3867.2004

[25] Tapper, M.A. and Hicks, R.E. (1998) Temperate Viruses and Lysogeny in Lake Superior Bacterioplankton. Limnology and Oceanography, 43, 95-103http://dx.doi.org/10.4319/lo.1998.43.1.0095

[26] Williamson, K.E., Schnitker, J.B., Radosevich, M., Smith, D.W. and Wommack, K.E. (2008) Cultivation-Based Assessment of Lysogeny among Soil Bacteria. Microbial Ecology, 56, 437-447. http://dx.doi.org/10.1007/s00248-008-9362-2 
[27] Proctor, B.L. and Gaulden, M.E. (1986) Chemical Stability of Mitomycin C in Culture Medium with and without Fetal Calf Serum as Determined by High Pressure Liquid Chromatography and Mass Spectrometry. Archives of Environmental Contamination and Toxicology, 15, 235-240. http://dx.doi.org/10.1007/BF01059972

[28] Hewson, I. and Fuhrman, J.A. (2006) Characterization of Lysogens in Bacterioplankton Assemblages of the Southern California Borderland. Microbial Ecology, 53, 631-638. http://dx.doi.org/10.1007/s00248-006-9148-3

[29] Weinbauer, M.G. (2004) Ecology of Prokaryotic Viruses. FEMS Microbiology Reviews, 28, 127-181. http://dx.doi.org/10.1016/j.femsre.2003.08.001

[30] Parada, V., Baudoux, A.-C., Sintes, E., Weinbauer, M. and Herndl, G.J. (2008) Dynamics and Diversity of Newly Produced Virioplankton in the North Sea. The Journal of International Society for Microbial Ecology, 2, 924-936. http://dx.doi.org/10.1038/ismej.2008.57

[31] Brock, T.D. and Brock, M.L. (1968) Relationship between Environmental Temperature and Optimum Temperature of Bacteria along a Hot Spring Thermal Gradient. Journal of Applied Microbiology, 31, 54-58.

[32] Winter, C., Smit, A., Herndl, G.J. and Weinbauer, M.G. (2004) Impact of Virioplankton on Archaeal and Bacterial Community Richness as Assessed in Seawater Batch Cultures. Applied and Environmental Microbiology, 70, 804-813. http://dx.doi.org/10.1128/AEM.70.2.804-813.2004

[33] Weinbauer, M.G. and Höfle, M.G. (1998) Distribution and Life Strategies of Two Bacterial Populations in a Eutrophic Lake. Applied and Environmental Microbiology, 64, 3776-3783.

[34] Connell, J.H. (1961) The Influence of Interspecific Competition and Other Factors on the Distribution of the Barnacle Chthamalus stellatus. Ecology, 42, 710-723. http://dx.doi.org/10.2307/1933500

[35] Riemann, L., Holmfeldt, K. and Titelman, J. (2009) Importance of Viral Lysis and Dissolved DNA for Bacterioplankton Activity in a P-Limited Estuary, Northern Baltic Sea. Microbial Ecology, 57, 286-294. http://dx.doi.org/10.1007/s00248-008-9429-0

[36] Wagner, P.L. and Waldor, M.K. (2002) Bacteriophage Control of Bacterial Virulence. Infection and Immunity, 70, 3985-3993. http://dx.doi.org/10.1128/IAI.70.8.3985-3993.2002

[37] Miller, R.V. and Day, M.J. (2008) Contribution of Lysogeny, Pseudolysogeny, and Starvation to Phage Ecology. In: Abedon, S.T., Ed., Bacteriophage Ecology: Population Growth, Evolution, and Impact of Bacterial Viruses, Chap. 5, Cambridge University Press, Cambridge, 114-143. http://dx.doi.org/10.1017/CBO9780511541483.008

[38] Wilson, M.S., Siering, P.L., White, C.L., Hauser, M.E. and Bartles, A.N. (2008) Novel Archaea and Bacteria Dominate Stable Microbial Communities in North America’s Largest Hot Spring. Microbial Ecology, 56, 292-305. http://dx.doi.org/10.1007/s00248-007-9347-6 